\title{
Realizing the Company's Energy Conservation Goal and Optimizing the Salary Management System - A Case Study of C Electric Power Company
}

\author{
Wang Yihan ${ }^{1, *}$ \\ ${ }^{1}$ HoHai University, Human Resource Management major, 211100 Nanjing, China
}

\begin{abstract}
It can be predicted that the development of energy conservation economy will be the long-term theme of struggle from the "energy conservation action of 1000 enterprises" launched during the "Eleventh Five Year Plan" to the "energy conservation action of 10000 enterprises" launched during the "Twelfth Five Year Plan". Salary management is an important part of enterprise management. Appropriate salary management can motivate employees to work hard towards the direction set by the organization and ultimately achieve the goal of the organization. Under the background of the development of energy conservation economy, this paper takes C Electric Power Company as the research object, analyzes the current situation of its salary management, and then points out the main problems existing in the current salary management of $\mathrm{C}$ Company, and puts forward reasonable solutions to these problems, so as to improve the salary management system level of C Company, eventually promote the gradual development of C Company towards the direction of energy conservation.
\end{abstract}

\section{Introduction}

During the "Eleventh Five Year Plan" period, China has launched a series of policies, including "energy conservation actions of 1000 enterprises", to deal with the increasingly prominent problem of resource and environmental constraints in China. C Electric Power Company, as a member of high energy consumption industry, has been included in the action. The implementation of "energy conservation action of 1000 enterprises" in the "Eleventh Five Year Plan" period has been fruitful2, and its practical experience has been further promoted in the "Twelfth Five Year Plan" period, forming the "energy conservation action of 10000 enterprises" policy4. Therefore, on the way of economic development in the future, energy conservation and environmental protection policies similar to "energy conservation action of 1000 enterprises" will continue to be introduced and implemented. Electric power enterprises play an important role in maintaining the normal life order. Under the new development situation, through the research and analysis of the internal salary system, further improving the incentive mechanism is conducive to the smooth development of work, and improve the enthusiasm of the company's internal staff, and enhance the overall management level. This paper uses the method of literature analysis to analyse and sort out the domestic and foreign literature of energy-saving economy and electric power enterprise salary management system, analyses the existing problems of $\mathrm{C}$ Company's salary management, and provides theoretical basis and literature for the follow-up suggestions to improve the salary system under the requirements of the development of energy conservation economy, so that the company can motivate employees to work hard towards the company's energy conservation goal. Finally, it will promote the improvement of C Company's salary system and the realization of the company's goals.

\section{C Company Salary Management Status and Energy Conservation Attitude}

C Company's salary system is composed of post salary accounting for the majority, performance salary as a supplement, and unified management and hierarchical formulation. C Company maintains scientific fairness in setting salary scales, and pays attention to fit with the local electric power industry talent market when establishing salary and welfare system, so as to improve the talent inflow rate, reduce the brain drain rate, strengthen the company's core strength, and finally achieve the company's objective of energy conservation. Due to the limitation of enterprise capacity, C Company adopts the market following policy, which is roughly consistent with the average salary level in the local market. It can not only maintain a certain ability to attract and retain employees, but also avoid falling into a disadvantageous position in the product market. The salary structure of the company mainly includes total salary, five insurances and one fund, welfare and other expenses. 
C Company lacks relevant experience in energy conservation management, and the administrators has a weak awareness of this. Under the pressure of the government and society, it is forced to take measures, but it does not start from the company itself.

\subsection{The reformation and innovation of salary system is not enough}

In recent years, $\mathrm{C}$ company is committed to the reformation of salary system, although it has achieved certain results, there are still many problems. The main performance is that the reforming is not enough, the company's salary system retains the traditional factors, and does not completely break the original system, that is, the lack of innovative incentive factors, and the degree of employee salary incentive is not significant. At present, the salary reformation and innovation of $\mathrm{C}$ Company need to be adjusted with the change of the company's development strategy and the market economy situation.

\subsection{The salary of employees is out of line with the market price}

After the current salary reformation in C Company, the salary level of most employees is out of line with the local market price. Some non-key employees are paid better than key employees, which leads to psychological imbalance of some employees. It means the existing salary management system of C Company violates the principle of fairness and justice, which leads to the loss of enthusiasm of employees for work, and eventually brain drain, which affects the long-term achievement of the company objective.

\subsection{The incompatibility between employee salary and enterprise value}

After C Company's salary reformation, employees' attitude towards work has a positive trend. Employees expect to realize their value through hard work and obtain considerable salary income. However, due to the incomplete reformation of C Company and the influence of traditional ideas, the current salary system still adopts the conventional distribution method, such as according to the "bureaucratic system", pay according to the different levels of departments3. For example, the salary is not adjusted according to the personal ability of the employees, but is still allocated according to the employees' own conditions. For example, the salary is linked to the education background of the employees, and is not reasonably allocated according to the actual situation of the company. The company emphasizes that the distribution according to work has not been implemented. As the most direct indicator of employee value is salary, the current salary system of C Company does not reflect the real value of employees.

\section{Problems in Salary Management System of C Company}

\subsection{The salary management appraisal system is separated from the enterprise's strategic objectives}

At present, $\mathrm{C}$ company adopts the domestic conventional salary evaluation system, which is decomposing the objectives layer by layer, and assign the company's tasks and responsibilities to specific individuals, which is an important basis and means for evaluating the performance of employees. However, in the actual implementation process, the company's administrators decomposes the goals under the influence of subtraction, which leads to the failure of mutual support between the decomposed goals. The final sum of the decomposed goals is less than 1 , and each department or employee only pursues their own goals, but ultimately cannot achieve the enterprise goals. Therefore, the salary system based on the decomposition of C Company's responsibility system has poor practical application effect, and it is difficult to provide a solid foundation and strong support for the company's strategic objectives.

\subsection{The inherent shortcomings of position salary system}

Because of the characteristics of the way of its production, the position salary system focuses on the value of the position itself, but pays little attention to the human factor, and keeps the ability of the employees who hold a certain position matching the standard that the work needs to achieve, which inevitably leads to the disadvantages of the position salary system in $\mathrm{C}$ Company. Firstly, the salary is directly linked to the position. If there is little hope of promotion, it means that the possibility of salary increase will also be restrained, which is bound to dampen the enthusiasm of employees. Secondly, the position is relatively stable, and the salary linked to the position will not change much, which is not conducive to timely incentive of employees. Thirdly, strengthening the difference between the position grades may lead to bureaucratic breeds. Compared with improving their work efficiency, employees will put more energy on promotion, which is not conducive to the enhancement of enterprise competitiveness and the diversion of achievement of energy conservation.

\subsection{The evaluation system is incomplete and the content of salary evaluation is single}

At present, the main content of C Company's salary assessment is the working hours of employees, the amount of tasks completed and the quality of work service. For other index factors, such as employees' work attitude, innovative opinions and communication and coordination ability, all of them are evaluated and approved by the leaders of human resources management department based on their intuitive impression. As a result, the actual contributions made by 
employees to the company are not included in the scope of performance, so the efforts of employees are not directly reflected in the salary. In addition, the assessment of C Company is carried out according to the year, which is not in line with its own attributes and positioning. There is no change and innovation, resulting in the lack of subjective initiative of employees, making the development of the company unable to adapt to the new situation of energy conservation. As shown in Table 1, although Company $\mathrm{C}$ 's economic indicators have improved, it still does not pay enough attention to performance appraisal, so it is difficult to play its incentive role.

Table 1. 5 C Company Economic and Technical Indicators

\begin{tabular}{|c|c|c|c|c|}
\hline Item & $\begin{array}{c}\text { Electricity } \\
\text { sales (100 } \\
\text { million } \\
\text { kwh) }\end{array}$ & $\begin{array}{c}\text { Growth } \\
\text { rate of } \\
\text { electricity } \\
\text { sales }\end{array}$ & $\begin{array}{c}\text { Line } \\
\text { loss } \\
\text { rate } \\
(\%)\end{array}$ & $\begin{array}{c}\text { Main } \\
\text { business } \\
\text { income } \\
(10000 \\
\text { yuan })\end{array}$ \\
\hline 2016 & 3.52 & 31.02 & 7.52 & 12743.19 \\
\hline 2017 & 4.65 & 28.65 & 7.23 & 17489.13 \\
\hline 2018 & 6.22 & 33.52 & 6.51 & 22456.67 \\
\hline
\end{tabular}

\subsection{The salary level doesn't adapt to the post value and industry standard}

C Company ignored the job analysis before the salary management, administrators only based on their own work experience to evaluate the job value, the measurement standard is not clear, subjectivity. Besides, randomness is dominant, ignoring the quantitative analysis of the job itself, including the nature and content of the work, work intensity and difficulty, as well as the key and particularity of the work and other objective factors, resulting in the loss of enterprise competitiveness so there is internal unfairness in the salary level of the company. At the same time, C Company did not conduct sufficient investigation in the labor market to understand the market salary level of each position. The salary of ordinary employees is excessively lower than the market level, and the salary provided by the company lacks external competition. Moreover, C Company always accustomed to pay employees in a single way, but the lack of demand survey of employees, not understanding the real needs of employees, make it difficult to maximize the value of enterprise compensation management. In the long run, unreasonable salary level is difficult to motivate employees, which will lead to the decrease of employee diligence for collectively realizing company objective.

\section{Solutions to the problems existing in salary management system of $\mathrm{C}$ Company}

\subsection{Coordinating salary management system and enterprise development strategy}

The company's development strategy and human resources should complement each other. In response to the national call, C Company should be committed to the development of energy-saving products, energy-saving technology, and improvement of energy efficiency. According to the company's development strategy, human resources should formulate corresponding management strategies. At the same time, appropriate human resources strategies can better support the company's development strategy. Salary management is the core content of human resource management, so salary management strategy should maximize the reflection of the company's development strategy and lay the foundation for the company's long-term development. For example, Huawei, Datang and other well-known technology enterprises, after years of development, Huawei is growing stronger and stronger, and can resist the competition and pressure of similar enterprises at home and abroad. Datang merged with Fiber home technology, and its brand has disappeared. Through the analysis, we can see that Huawei's great success is closely related to its effective human resource management. Huawei has invested a lot in human resources, obtained a large number of talents, and become the first choice of domestic well-known college graduates. The continuous supply of excellent talents has successfully promoted the development of the company. For electric power enterprises, the same is true. Only reasonable use of talents can ensure the continuous development of enterprises. Reasonable salary management system can connect employees and enterprises, employees sincerely contribute to the development of the company, and become a solid human resource foundation of the company.

Under the requirements of energy conservation, C Company should pay more attention to energy conservation management, set up a special energy conservation Organization Department within the enterprise, equip professional staff to carry out energy conservation work1, and bring it into the salary system.

\subsection{Establish a balanced salary system}

For the sake of fairness and justice, the overlapping part of the salary range between adjacent salary grades should be appropriately reduced on the original basis, which minimizes the loss of the reduction of salary growth opportunities for those who have not been promoted. In addition, the salary growth opportunities of those who have been promoted are increased, so that they are more motivated, and the possibility of improving work efficiency is also increased.

After adjusting the salary structure, it is inevitable that the salary of employees at different post levels will 
change, either increase or decrease. For those whose new salary level is higher than the original, the first thing to do is to quantify and sort the work results of these employees, and pay them according to the higher salary level. For the employees whose salary is reduced, it cannot directly reduce their original salary, but help them to analyze and take effective measures to train them to strengthen their skills and improve work efficiency. And the margin below the original salary, it is best to be classified as allowance or other forms of payment, so as to calm the dissatisfaction of employees and enhance the cohesion of the enterprise.

\subsection{Combine salary management with performance management}

The administrators of the company should realize that the incentive of high salary to talents is limited. Only by combining the salary system with the performance appraisal system, can the enthusiasm of employees be better stimulated, and the employees can give full endeavor to their personal ability. Performance feedback will not only affect the company's current strategic behavior, but also affect the company's future performance. C Company should change the previous salary composition, take performance pay as an important part, and bring it into the salary management system. At present, most companies adopt a flexible salary system, gradually increase the weight of performance work, and begin to abandon the traditional fixed salary system. This compensation system has a clear incentive oriented function, which can maximize the incentive of employees and is extremely beneficial to the development of the company.

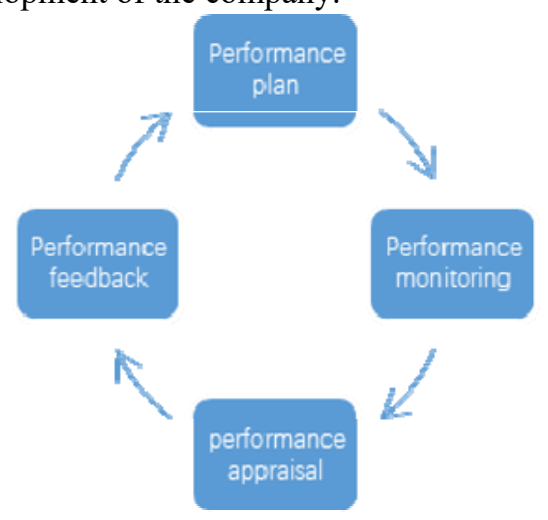

Fig. 1. Performance Management Flow Chart

\subsection{Conduct job analysis and salary market research}

The fairness of salary level directly affects the work enthusiasm and turnover rate of employees. Therefore, it is necessary to make the salary system fair and objective. To achieve external equity, we need to conduct a full investigation of the salary market, while internal equity needs to be solved through job analysis. Through the external market survey, we can understand the power industry market salary level and change trend, as well as the economic development of the whole market. In order to enhance the attractiveness of enterprise talents, we must keep the enterprise salary level above the average level of the market. Through job analysis, we can make up for the missing again, so as to make the enterprise salary level reach a reasonable standard. In a word, the enterprise should consider its own benefit growth, local average wage and minimum wage standard to determine the enterprise wage level and growth rate. In addition, the price level cannot be ignored.

\section{Conclusions}

With the rapid development of national economy, the level of national economy is constantly improving, and the salary and welfare of employees are also gradually improving. The achievement of company objectives has a close relationship with the introduction of talents. Talents enter the enterprise through recruitment to become employees, and then get the corresponding remuneration by working for the enterprise, while the enterprise relies on employees to achieve business operation. In order to attract more talents, enterprises must attach enough importance to the internal salary management system, so the competition between enterprises is gradually changed from the competition between talents to the competition on the salary management system. As a result, this paper draws a conclusion through the research:

The administrators of C Company should attach great importance to the reformation of the current salary system of the company, change the management concept of the salary system, establish a perfect salary management system according to the specific situation, solve the problems existing in the current salary system, effectively implement the incentive function of salary, take more suitable talents for our own use, maintain the harmonious relationship between labor and capital, and enhance the enthusiasm of employees. At the same time, maintain good enterprise loyalty, and then form greater work motivation, lay the core foundation for the company to achieve the goal of energy conservation. At the meantime, it also explores its own characteristic development path to provide successful experience for other enterprises.

\section{References}

1. Lu, H. Research on Influencing Factors of Enterprise Energy Saving Behaviour under the Background of New Economy. D. Tianjin University of Technology (2017)

2. Price L, Wang, X., Yun, J. The Challenge of Reducing Energy Consumption of the Top-1000 Largest Industrial Enterprises in China. J. Energy Policy, 38(11):6485-6498 (2010)

3. Wang, L., Ji, D. Optimizing Human Resources Performance Compensation Management in Electric Power Enterprises. J. Human Resources, 18: 78-79 (2020) 
4. Xiao, Y. Will Environmental Regulation Damage the Competitiveness of Enterprises?. D. Shanghai Jiao Tong University (2017)

5. Zheng, Y. Optimization Design of Salary Management System in Electric Power Enterprises.

J. Times Finance, 35: 61-62 (2019) 